\title{
Role of Gi Proteins in the Antidepressant-like Effect of Amitriptyline and Clomipramine
}

\author{
Nicoletta Galeotti, Ph.D., Alessandro Bartolini, M.D., and Carla Ghelardini, Ph.D.
}

The effect of the i.c.v. administration of pertussis toxin (PTX) and antisense oligodeoxynucleotides directed against the $\alpha$ subunit of different Gi-proteins (anti-Gi $\alpha_{1}$, anti-Gi $\alpha_{2}$, anti-Gi $\alpha_{3}$, anti-Go $\alpha_{1}$, anti-Go $\alpha_{2}$ ) on the antidepressant-like effect induced by amitriptyline and clomipramine, was evaluated in the mouse forced swimming test, an animal model of depression. The administration of amitriptyline $\left(15 \mathrm{mg} \mathrm{kg}^{-1}\right.$ s.c.) and clomipramine $\left(25 \mathrm{mg} \mathrm{kg}^{-1}\right.$ s.c.) produced an increase in the mobility time that was prevented by PTX (0.25 $\mu \mathrm{g}$ per mouse i.c.v.), administered 11 days before the mouse forced swimming test. Anti-Gia $\alpha_{1}$

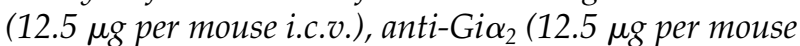
i.c.v.), anti-Gi $\alpha_{3}\left(6.25 \mu \mathrm{g}\right.$ per mouse i.c.v.), and anti-Go $\alpha_{1}$ (6.25 $\mu \mathrm{g}$ per mouse i.c.v.), administered 24 and $18 \mathrm{~h}$ before the training session, prevented the amitriptyline and clomipramine increase of the mobility time. By contrast, pretreatment with anti-Go $\alpha_{2}$ (1.56-12.5 $\mu \mathrm{g}$ per mouse i.c.v.) never modified the antidepressant-like effect induced by the two investigated compounds. At the highest effective doses, none of the compounds used impaired motor coordination, as revealed by the rota-rod test, nor modified spontaneous motility and inspection activity, as revealed by the hole-board test. These results suggest the important role played by $G i_{1}, G i_{2}, G i_{3}$, and $G o_{1}$ protein subtypes and the lack of involvement by $\mathrm{Go}_{2}$ protein subtype in the transduction mechanism responsible for the antidepressantlike effect produced by amitriptyline and clomipramine.

[Neuropsychopharmacology 27:554-564, 2002]

(C) 2002 American College of Neuropsychopharmacology.

Published by Elsevier Science Inc.
KEY WORDS: Amitriptyline; Clomipramine; Tricyclic antidepressants; Pertussis toxin; Gi-proteins; Antisense oligodeoxyribonucleotides

For the past several decades, antidepressant drugs have been widely used in the treatment of clinical depression and other psychiatric disorders. Several distinct pharmacological compounds show therapeutic efficacy. These include monoamine oxidase inhibitors, tricyclic compounds, selective serotonin and norepinephrine reuptake inhibi-

From the Department of Preclinical and Clinical Pharmacology, University of Florence, Florence, Italy

Address correspondence to: Dr. Carla Ghelardini, Dept. of Pharmacology, Viale G. Pieraccini 6, 6I-50139 Florence, Italy. Tel.: +39 055 4271312; Fax: +39 055 4271280; E-mail: ghelard@pharm.unifi.it

Received November 6, 2001; revised March 22, 2002; accepted March 25, 2002.

Online publication: $3 / 27 / 02$ at www.acnp.org/citations/ Npp032702274. tors, as well as some atypical drugs. Numerous studies have examined the effects of antidepressants on neurotransmitter metabolism, turnover, and receptor sensitivity and several theories on their mechanism of action have been proposed. These include the inhibition of monoamine transporter activity in presynaptic membranes (Schildkraut 1965), downregulation of $\beta$-adrenoceptors (Mazzola-Pomietto et al. 1994), alteration at cholinergic, dopaminergic or GABAergic receptors (Henringer and Charney 1987). However, the molecular mechanism of action underlying the therapeutic effect of antidepressants is still unclear.

Despite their diversity, these treatments subserve the same final clinical effect. Therefore, the possibility that these diverse agents converge on a single postreceptorial target evoked a great research interest. Since most neurotransmitter receptors and neuromodulators are coupled to intracellular effectors through G-proteins (Birnbaumer 1990), recent studies searching for a com- 
mon mechanism of antidepressant action have focused on G-proteins as a potential target of such action.

G-proteins are a ubiquitous family of proteins that play a crucial role in transducing extracellular signals to cellular targets, thus transmitting messages from cell surface receptors to cellular effectors including adenylate cyclase, phospholipase $C$ and ion channels (Sprang 1997). G-proteins are heterotrimeric molecules with $\alpha, \beta$ and $\gamma$ subunits. The $\alpha$ subunits can be classified into families, depending on whether they are targets for cholera toxin (Gs), pertussis toxin (PTX) (Gi and Go) or neither $\left(\mathrm{Gq}\right.$ and $\left.\mathrm{G}_{12}\right)$ (Simon et al. 1991). A growing body of evidence suggests that G-proteins are the molecular target of many antidepressants. Menkes et al. (1983) first reported that long-term administration of various antidepressants enhanced guanylyl-5'-imidodiphosphate and fluoride-stimulated adenylyl cyclase activity in rat cortex and hypothalamus membranes suggesting Gs-protein as target for antidepressant action. These initial findings involving the stimulation of adenylyl cyclase via Gs-proteins after antidepressant treatment was further supported by later studies (Yamaoka et al. 1988; Ozawa and Rasenick 1989; Kamada et al. 1999). Furthermore, increased expression and activity of cAMP response element binding protein has been demonstrated in various rat brain regions, such as hippocampus, cerebral cortex, amygdala, and hypothalamus (Nibuya et al. 1996; Duman et al. 1997; Thome et al. 2000). Recently, it has been suggested that chronic treatment with antidepressant drugs induces modification of the coupling between Gs-coupled receptors and adenylate cyclase in C6 glioma cells (Donati et al. 2001).

Pertussis toxin-sensitive G-proteins ( $\mathrm{G}_{\mathrm{i}}$-proteins) represent the most widespread modulatory signaling pathway in neurones (Holtz et al. 1986) and are responsible for inhibition of adenylate cyclase activity and modulation of several $\mathrm{K}^{+}$and $\mathrm{Ca}^{2+}$ channels (Hille 1994; Sprang 1997). Contrary to Gs-proteins, the role of Giproteins in the mechanism of action of antidepressant drugs is more controversial. Chronic treatment with antidepressant drugs has been reported to produce a reduction of $\mathrm{Gi}_{\alpha}$ and an increase of the $\mathrm{Go}_{\alpha}$ protein levels (Lesch et al. 1991; Lesch and Manji 1992; Raap et al. 1999) in various regions of rat brain, including neostriatum, hypothalamus, frontal cortex and midbrain. By contrast, no alteration of $\mathrm{Gi}_{\alpha}$ and $\mathrm{Go}_{\alpha}$ protein and mRNA levels in rat brain (cortex, hippocampus, cerebellum) was observed after chronic treatment with tricyclic antidepressants (TCA) and monoamine oxidase inhibitors (Li et al. 1993; Chen and Rasenick 1995; Emamghoreishi et al. 1996; Dwivedi and Pandey 1997).

In light of these controversial data, the aim of the present study was to further elucidate the role of the Giprotein family in the mechanism of action of antidepressant drugs. In particular, we used antisense oligo- nucleotides (aODN) against the $\alpha$ subunits of the $\mathrm{Gi}_{1}$, $\mathrm{Gi}_{2}, \mathrm{Gi}_{3}, \mathrm{Go}_{1}$ and $\mathrm{Go}_{2}$ proteins in order to determine the role of each subtype in the antidepressant-like effect induced by amitriptyline and clomipramine in the mouse forced swimming test. In order to exclude that the effects produced by aODN treatments were due to the induction of side effects, some additional behavioral tests (rota-rod, hole-board) were performed.

\section{METHODS}

\section{Animals}

Male Swiss albino mice (23-25 g) from the Morini (San Polo d'Enza, Italy) breeding farm were used. Fifteen mice were housed per cage $(26 \times 41 \mathrm{~cm})$. The cages were placed in the experimental room $24 \mathrm{~h}$ before the test for acclimatization. The animals were fed a standard laboratory diet and tap water ad libitum and kept at $23 \pm 1{ }^{\circ} \mathrm{C}$ with a $12 \mathrm{~h} \mathrm{light/dark}$ cycle, light on at 7 A.M. All experiments were carried out in accordance with the Guide for the Care and Use of Laboratory Animals as adopted and promulgated by the National Institutes of Health.

\section{Intracerebroventricular Injection Technique}

Intracerebroventricular (i.c.v.) administration was performed under ether anesthesia, according to the method described by Haley and McCormick (1957). Briefly, during anesthesia, mice were grasped firmly by the loose skin behind the head. A $0.4 \mathrm{~mm}$ external diameter, hypodermic needle attached to a $10 \mu l$ syringe was inserted perpendicularly through the skull and no more than $2 \mathrm{~mm}$ into the brain of the mouse, where $5 \mu \mathrm{l}$ were then administered. The injection site was $1 \mathrm{~mm}$ to the right or left from the midpoint on a line drawn through to the anterior base of the ears. Injections were performed into the right or left ventricle randomly. To ascertain that the drugs were administered exactly into the cerebral ventricle, some mice $(20 \%)$ were injected with $5 \mu \mathrm{l}$ of diluted 1:10 India ink and their brains examined macroscopically after sectioning. The accuracy of the injection technique was evaluated and the percentage of correct injections was determined to be 95 .

\section{Forced Swimming Test}

The forced swimming test used was the same as described by Porsolt et al. (1977). Briefly, mice were dropped individually into glass cylinders (height: $25 \mathrm{~cm}$, diameter: $10 \mathrm{~cm}$ ) containing $6 \mathrm{~cm}$ of water maintained at $22-23^{\circ} \mathrm{C}$ and left there for $6 \mathrm{~min}$. A mouse was judged 
to be immobile when it floated in the water, in an upright position, and made only small movements to keep its head above water. The duration of mobility was recorded during the last $4 \mathrm{~min}$ of the 6-min test. An increase in the duration of mobility is indicative of an antidepressant-like effect. The test was performed $24-18 \mathrm{~h}$ after i.c.v. injections of ODNs, 11 days after PTX administration, $30 \mathrm{~min}$ after tricyclic antidepressant injection.

\section{Hole-board Test}

The hole-board test consisted of a $40 \mathrm{~cm}$ square plane with 16 flush mounted cylindrical holes ( $3 \mathrm{~cm}$ diameter) distributed 4 by 4 in an equidistant grid. Mice were placed on the center of the board one by one and allowed to move about freely for a period of $10 \mathrm{~min}$ each. Two electric eyes, crossing the plane from mid-point to mid-point of opposite sides, thus dividing the plane into four equal quadrants, automatically signaled the movement of the animal (counts in $5 \mathrm{~min}$ ) on the surface of the plane (locomotor activity). Miniature photoelectric cells, in each of the 16 holes, recorded (counts in $5 \mathrm{~min}$ ) the exploration of the holes (exploratory activity) by the mice. The test was performed 18-24 $\mathrm{h}$ after the i.c.v. injections of degenerate ODN (dODN) or aODN, 11 days after administration of PTX. 12-15 mice per group were tested.

\section{Rota-rod Test}

The apparatus consisted of a base platform and a rotating rod with a diameter of $3 \mathrm{~cm}$ and a non-slippery surface. The rod was placed at a height of $15 \mathrm{~cm}$ from the base. The rod, $30 \mathrm{~cm}$ in length, was divided into five equal sections by six disks. Thus, up to five mice were tested simultaneously on the apparatus, with a rod rotating speed of $16 \mathrm{rpm}$. The integrity of motor coordination was assessed on the basis of the number of falls from the rod in $30 \mathrm{~s}$ according to Vaught et al. (1985). Those mice scoring less than three and more than six falls in the pretest were rejected $(20 \%)$. The performance time was measured before (pretest) and 15, 30 and $45 \mathrm{~min}$ after s.c. treatment. Animals were i.c.v. pretreated $24-18 \mathrm{~h}$ prior to the test with degenerate ODN
(dODN) or aODN or 11 days before the test with PTX. 12-15 mice per group were tested.

\section{Antisense Oligonucleotides}

The sequences of the antisense oligonucleotides used in the present study are shown in Table 1 .

Phosphodiester ODNs protected from terminal phosphorothioate double substitution (capped ODNs) against possible exonuclease-mediated degradation were used (Tib Molbiol, Genova, Italy). A 33-mer fully degenerated ODN (dODN) $5^{\prime}-\mathrm{N}^{*} \mathrm{~N}^{*} \mathrm{~N}$ NNN NNN NNN NNN NNN NNN NNN NNN NNN N*N*N - ${ }^{\prime}$ (where $\mathrm{N}$ is $\mathrm{G}, \mathrm{C}, \mathrm{A}$, or $\mathrm{T}$ ) and a 25-mer fully degenerated ODN (dODN) $5^{\prime}-\mathrm{N}^{*} \mathrm{~N}^{*} \mathrm{~N}$ NNN NNN NNN NNN NNN NNN $N^{*}{ }^{*}{ }^{*} \mathrm{~N}-3^{\prime}$ (where $\mathrm{N}$ is $\mathrm{G}, \mathrm{C}, \mathrm{A}$, or $\mathrm{T}$ ) were used as a control respectively for anti-Gi $\alpha$ and anti-Go $\alpha$. ODNs were vehiculated intracellularly by an artificial cationic lipid (DOTAP, Sigma) to enhance both uptake and stability, as described previously (Capaccioli et al. 1993). aODN or dODN were preincubated at $37^{\circ} \mathrm{C}$ for $30 \mathrm{~min}$ with $13 \mu \mathrm{M}$ DOTAP and supplied to mice by i.c.v. injection of $5 \mu \mathrm{l}$ solution 18 and $24 \mathrm{~h}$ prior to the behavioral tests. All ODNs were previously characterized by in vitro (immunoblotting) and in vivo (tail flick) experiments (Kleuss et al. 1991; Raffa et al. 1994; Sanchez-Blazquez et al. 1995; Sanchez-Blazquez and Garzon 1998). We also confirmed the aODN effect on $\mathrm{G} \alpha$ protein levels by performing immunoblotting experiments. We observed a statistically significant reduction of the expression of $\mathrm{Gi} \alpha_{1}, \mathrm{Gi} \alpha_{2}, \mathrm{Gi} \alpha_{3}, \mathrm{Go} \alpha_{1}$ and $\mathrm{Go}_{2}$ subunits after aODN treatment in comparison with mice treated with dODN (data not shown).

\section{Drugs}

The following drugs were used: pertussis toxin (RBI); clomipramine hydrochloride amitriptyline hydrochloride, DOTAP (Sigma); D-amphetamine hydrochloride (De Angeli). All drugs were dissolved in isotonic $(\mathrm{NaCl}$ $0.9 \%$ ) saline solution immediately before use, except for pertussis toxin which was dissolved in a water solution containing $0.01 \mathrm{M}$ sodium phosphate buffer, $\mathrm{pH}=7.0$, with $0.05 \mathrm{M}$ sodium chloride. Drug concentrations were prepared in such a way that the necessary dose could

Table 1. Sequences of Antisense Oligonucleotides

\begin{tabular}{|c|c|}
\hline aODN & Sequences \\
\hline anti-Gi $\alpha_{1}$ & 5'- G*C*T GTC CTT CCA CAG TCT CTT TAT GAC GCC G*G*C -3' \\
\hline anti-Gi $\alpha_{2}$ & $5^{\prime}-A^{*} T^{*}$ G GTC AGC CCA GAG CCT CCG GAT GAC GCC C ${ }^{*} \mathrm{G}^{*} \mathrm{~A}-3^{\prime}$ \\
\hline anti-Gi $\alpha_{3}$ & $5^{\prime}-\mathrm{G}^{*} \mathrm{C}^{*} \mathrm{C}$ ATC TCG CCA TAA ACG TTT AAT CAC GCC $\mathrm{T}^{*} \mathrm{G}^{*} \mathrm{C}-3^{\prime}$ \\
\hline anti-Go $\alpha_{1}$ & $5^{\prime}-A^{*} G^{*}$ G CAG CTG CAT CTT CAT AGG TG*T *T $-3^{\prime}$ \\
\hline anti-Go $\alpha_{2}$ & $5^{\prime}-\mathrm{G}^{*} \mathrm{~A}^{*} \mathrm{G}$ CCA CAG CTT CTG TGA AGG CA*C ${ }^{*} \mathrm{~T}-3^{\prime}$ \\
\hline
\end{tabular}


be administered in a volume of $10 \mathrm{ml} \mathrm{kg}^{-1}$ by s.c. injection or $5 \mu$ l per mouse by i.c.v. injection.

\section{Statistical Analysis}

All experimental results are given as the mean \pm SEM Analysis of variance (ANOVA), followed by Fisher's Protected Least Significant Difference (PLSD) procedure for post-hoc comparison, was used to verify significance between two means. Data were analyzed with the StatView software for the Macintosh, 1992 version. $p$ values of less than .05 were considered significant.

\section{RESULTS}

\section{Effect of Pertussis Toxin on TCAs Antidepressant-like Effect}

Amitriptyline (15 mg kg-1 s.c.) and clomipramine (25 $\mathrm{mg} \mathrm{kg}^{-1}$ s.c.), injected $30 \mathrm{~min}$ before the test, induced an increase of the mobility time in the mouse forced swimming test (Figure 1). Pretreatment with pertussis toxin (PTX), injected i.c.v. at the dose of $0.25 \mu \mathrm{g}$ per mouse 11 days before the test, completely prevented the amitriptyline and clomipramine antidepressant-like effect (Figure 1).

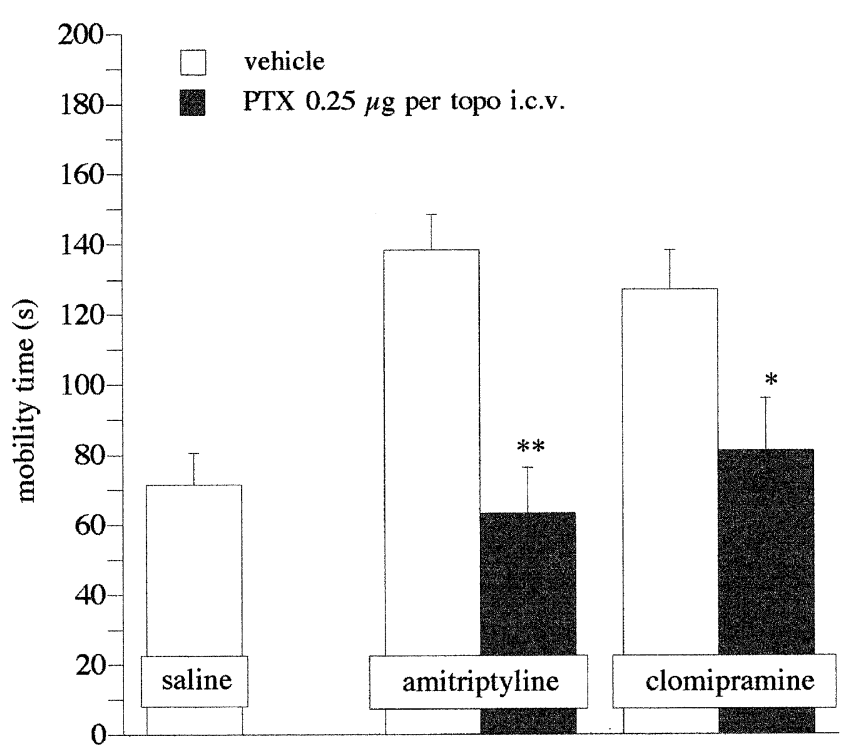

Figure 1. Prevention by pertussis toxin (PTX) of amitriptyline- and clomipramine-induced increase of the mobility time in the mouse forced swimming test. The test was performed 11 days after a single i.c.v. injection of vehicle or PTX $\left(0.25 \mu \mathrm{g}\right.$ per mouse). Amitriptyline $\left(15 \mathrm{mg} \mathrm{kg}^{-1}\right.$ s.c.) and clomipramine ( $25 \mathrm{mg} \mathrm{kg}^{-1}$ s.c.), were administered $30 \mathrm{~min}$ before the test. Between 19 and 25 mice were tested. Vertical lines represent SEM. ${ }^{*} p<.05$ in comparison with vehicle + clomipramine, ${ }^{* *} p<.01$ in comparison with vehicle + amitriptyline treated mice.

\section{Effect of aODN against Gi $\alpha$ Subunits on TCA-induced Antidepressant-like Effect}

The increase of mobility time induced by amitriptyline (15 $\mathrm{mg} \mathrm{kg}^{-1}$ s.c.) and clomipramine $\left(25 \mathrm{mg} \mathrm{kg}^{-1}\right.$ s.c.) was prevented, in the mouse forced swimming test, by pretreatment with the aODN against the $\alpha$ subunit of the Gi proteins (Figures 2-4). Anti-Gi $\alpha_{1}$ (3.12-12.5 $\mu \mathrm{g}$ per mouse i.c.v.) produced a dose-dependent antagonism of the TCA-induced antidepressant-like effect. The dose of $3.12 \mu \mathrm{g}$ per mouse i.c.v. was completely ineffective whereas the maximum effect was obtained at $12.5 \mu \mathrm{g}$ per mouse i.c.v. (Figure 2).

Similarly, anti-Gi $\alpha_{2}$ at $3.12 \mu \mathrm{g}$ per mouse i.c.v. was devoid of any effect; at $6.25 \mu \mathrm{g}$ per mouse i.c.v. partially prevented the TCA effect, even if the statistical significance was not reached, whereas the dose of $12.5 \mu \mathrm{g}$ per mouse i.c.v. reduced the mobility time up to a value comparable to that produced by control animals (Figure 3).

The administration of an aODN against the $\alpha$ subunit of the $\mathrm{Gi}_{3}$ proteins (1.56-6.25 $\mu$ g per mouse i.c.v.) antagonized the increase of mobility time produced by amitriptyline and clomipramine reaching its maximum effect at $6.25 \mu \mathrm{g}$ per mouse i.c.v. (Figure 4). Anti-Gi $\alpha_{1}$ (12.5 $\mu$ g per mouse i.c.v.), anti-Gi $\alpha_{2}(12.5 \mu$ g per mouse i.c.v.), and anti-Gi $\alpha_{3}(6.25 \mu \mathrm{g}$ per mouse i.c.v.) did not produce any modification of the mobility time in the mouse forced swimming test in comparison with i.c.v. saline- (data not shown) and dODN-treated mice when given alone (Figures 2-4).

\section{Effect of aODN against Go $\alpha$ Subunits on TCA-induced Antidepressant-like Effect}

Anti-Go $\alpha_{1}$ (1.56-6.25 $\mu$ g per mouse i.c.v.) produced a dosedependent antagonism of the increase in the mobility time of mice induced by both amitriptyline and clomipramine. The maximum effect of anti-Go $\alpha_{1}$ was reached at the doses of $6.25 \mu \mathrm{g}$ per mouse i.c.v., concentration that did not modify the mobility time of animals, in comparison with control group, when administered alone (Figure 5). The administration of an aODN against the $\alpha$ subunit of the $\mathrm{Go}_{2}$ proteins (1.56-12.5 $\mu \mathrm{g}$ per mouse i.c.v.), in contrast to anti-Go $\alpha_{1}$, was unable to prevent the TCA-induced antidepressant-like effect (Figure 6).

\section{Effect of aODN against Gi $\alpha$ and Go $\alpha$ Subunits on Mouse Rota-rod and Hole-board Tests}

It should be noted that the tricyclic antidepressants (amitriptyline, clomipramine) and the aODNs under investigation elicited their modulatory effects on mobility time in the forced swimming test without changing gross behavior, motor coordination (as revealed by the rota-rod test (Figure 7), spontaneous motility, or inspection activity, as revealed by the hole-board test (Table 


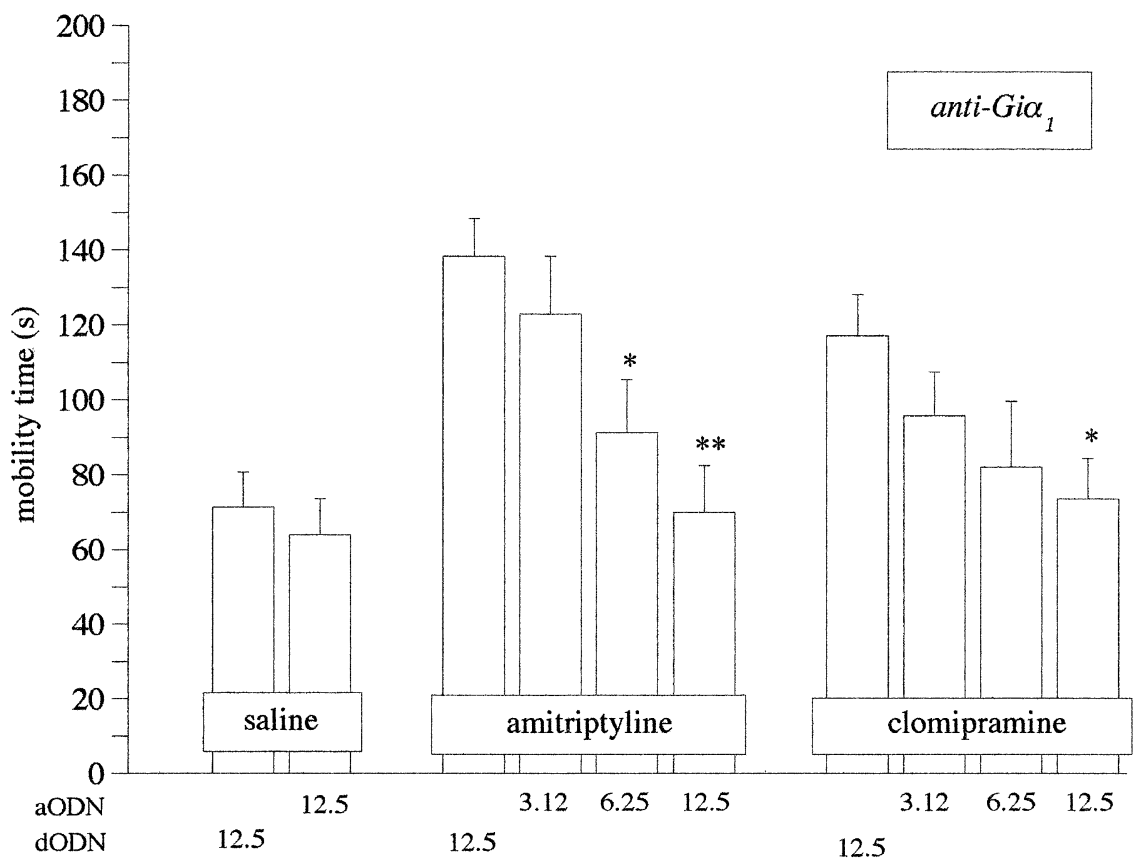

Figure 2. Prevention by pretreatment with an antisense oligonucleotide (aODN) to the $\alpha$ subunit of $\mathrm{Gi}_{1}$-protein gene (3.12-12.5 $\mu \mathrm{g}$ per mouse i.c.v.) of amitriptyline (15 $\mathrm{mg} \mathrm{kg}^{-1}$ s.c.)- and clomipramine $\left(25 \mathrm{mg} \mathrm{kg}^{-1}\right.$ s.c.)-induced antidepressant-like effect in the mouse forced swimming test. The test was performed $18-24 \mathrm{~h}$ after the i.c.v. injection of degenerate ODN (dODN; $12.5 \mu \mathrm{g}$ per mouse i.c.v.) or aODN. Between 16 and 23 mice were tested. Vertical lines represent SEM; the dose administered is reported below each column. ${ }^{*} p<.05$, ${ }^{*} p<.01$ in comparison with the corresponding TCA.
2).] The doses of amitriptyline and clomipramine of respectively 15 and $25 \mathrm{mg} \mathrm{kg}^{-1}$ s.c. did not modify the number of falls from the rotating rod in comparison with saline-treated mice. Each group progressively reduced its number of falls because mice learned how to balance on the rotating rod. Higher doses of amitriptyline (30 $\mathrm{mg} \mathrm{kg}^{-1}$ s.c.) and clomipramine $\left(45 \mathrm{mg} \mathrm{kg}^{-1}\right.$ s.c.) produced an increase in the number of falls indicating the presence of motor incoordination (Figure 7, panel A). The motor coordination of mice pretreated with aODN to $\mathrm{Gi}_{1} \alpha$ (12.5 $\mu$ g per mouse i.c.v.), $\mathrm{Gi}_{2} \alpha$ (12.5 $\mu \mathrm{g}$ per mouse i.c.v.), $\mathrm{Gi}_{3} \alpha(6.25 \mu \mathrm{g}$ per mouse i.c.v.), $\mathrm{Go}_{1} \alpha\left(6.25 \mu \mathrm{g}\right.$ per mouse i.c.v.), and $\mathrm{Go}_{2} \alpha(12.5 \mu \mathrm{g}$ per mouse i.c.v.) was evaluated by using the rota-rod test. The number of falls of aODN-treated groups was comparable to that of the dODN-treated mice (Figure 7, panel B). The spontaneous motility and exploratory activity of mice was not modified by administration of amitriptyline, clomipramine, PTX, and the above-mentioned aODNs as revealed by the hole-board test in comparison with saline-, vehicle- and dODN-treated mice (Table 2). In the same experimental conditions

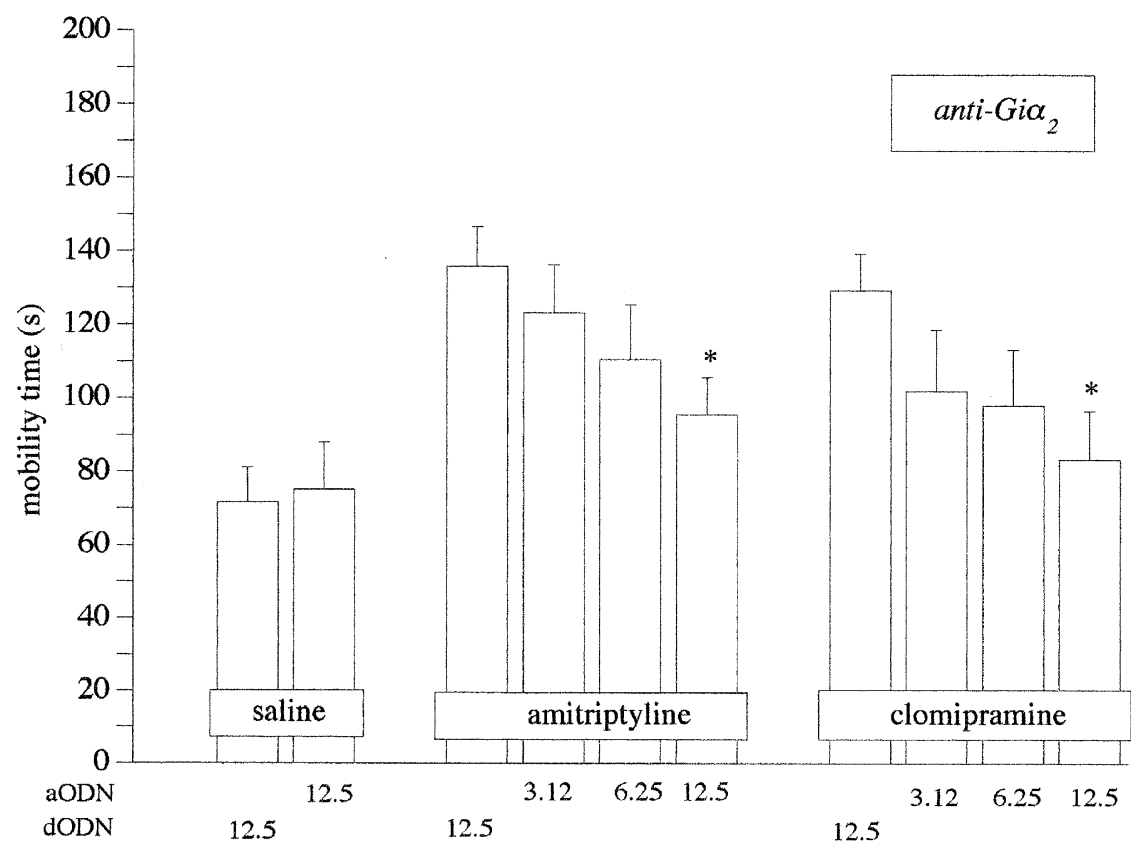

Figure 3. Prevention by pretreatment with an antisense oligonucleotide (aODN) to the $\alpha$ subunit of $\mathrm{Gi}_{2}$-protein gene (3.12-12.5 $\mu \mathrm{g}$ per mouse i.c.v.) of amitriptyline (15 $\mathrm{mg} \mathrm{kg}^{-1}$ s.c.)- and clomipramine ( $25 \mathrm{mg} \mathrm{kg}^{-1}$ s.c.)-induced antidepressant-like effect in the mouse forced swimming test. The test was performed $18-24 \mathrm{~h}$ after the i.c.v. injection of degenerate ODN (dODN; 12.5 $\mu \mathrm{g}$ per mouse i.c.v.) or aODN. Between 18 and 23 mice were tested. Vertical lines represent SEM; the dose administered is reported below each column. ${ }^{*} p<.05$ in comparison with the corresponding TCA. 


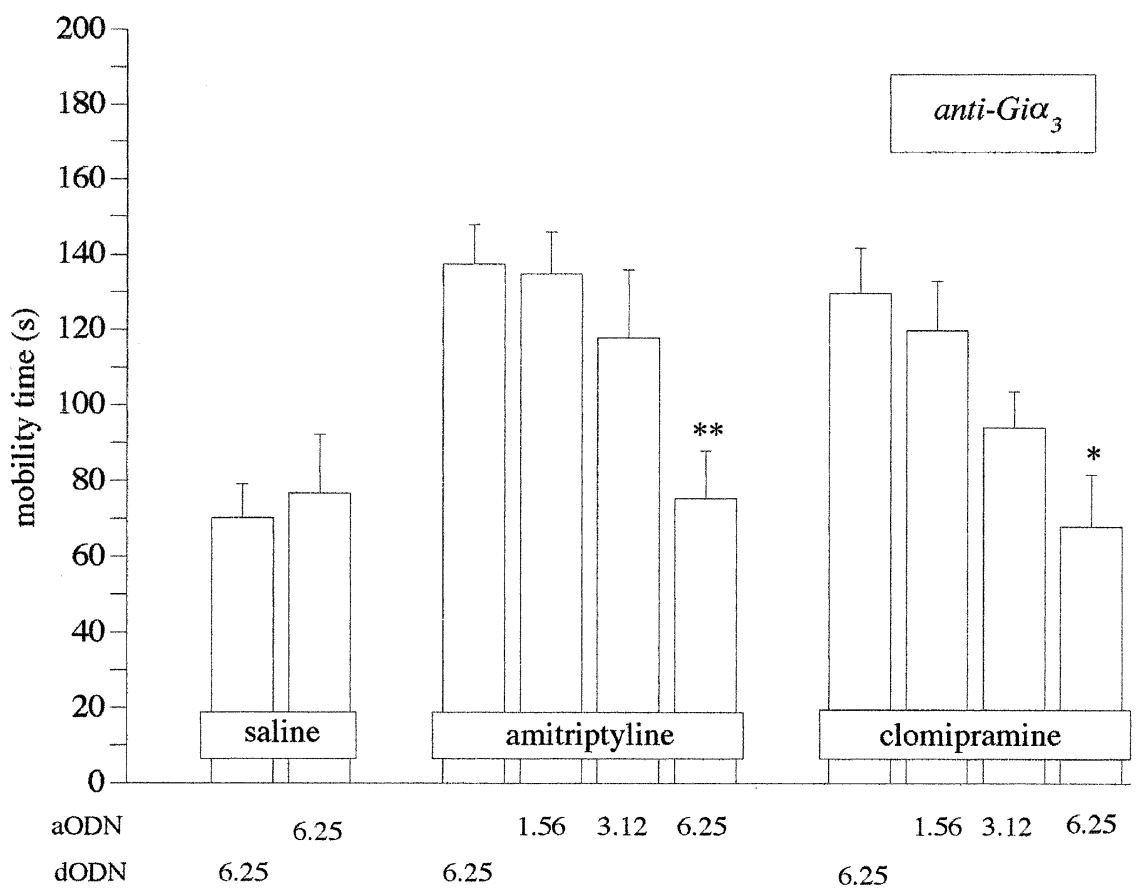

Figure 4. Prevention by pretreatment with an antisense oligonucleotide (aODN) to the $\alpha$ subunit of $\mathrm{Gi}_{3}$-protein gene (1.56-6.25 $\mu \mathrm{g}$ per mouse i.c.v.) of amitriptyline (15 $\mathrm{mg} \mathrm{kg}^{-1}$ s.c.)- and clomipramine (25 mg kg $\mathrm{mg}^{-1}$ s.c.)-induced antidepressant-like effect in the mouse forced swimming test. The test was performed 18-24 $\mathrm{h}$ after the i.c.v. injection of degenerate ODN (dODN; $12.5 \mu \mathrm{g}$ per mouse i.c.v.) or aODN. Between 16 and 21 mice were tested. Vertical lines represent SEM; the dose administered is reported below each column. ${ }^{*} p<$ $.05,{ }^{* *} p<.001$ in comparison with the corresponding TCA.
D-amphetamine (2 $\mathrm{mg} \mathrm{kg}^{-1}$ s.c.), used as the reference drug, increased both parameters evaluated.

\section{DISCUSSION}

Signal transduction mechanisms involved in the antidepressant-like effect produced by amitriptyline and clomipramine, two compounds belonging to the tricyclic antidepressant class, have been investigated in the mouse forced swimming test. The forced swimming test is widely used to predict the antidepressant action of drugs in humans. The mobility time of mice in this test is increased by the majority of antidepressants including tricyclic and atypical antidepressants, MAO inhibitors and 5-HT uptake inhibitors (Porsolt et al. 1977; Bourin et al. 1991), and their effectiveness correlates significantly with clinical potency (Willner 1984). However,

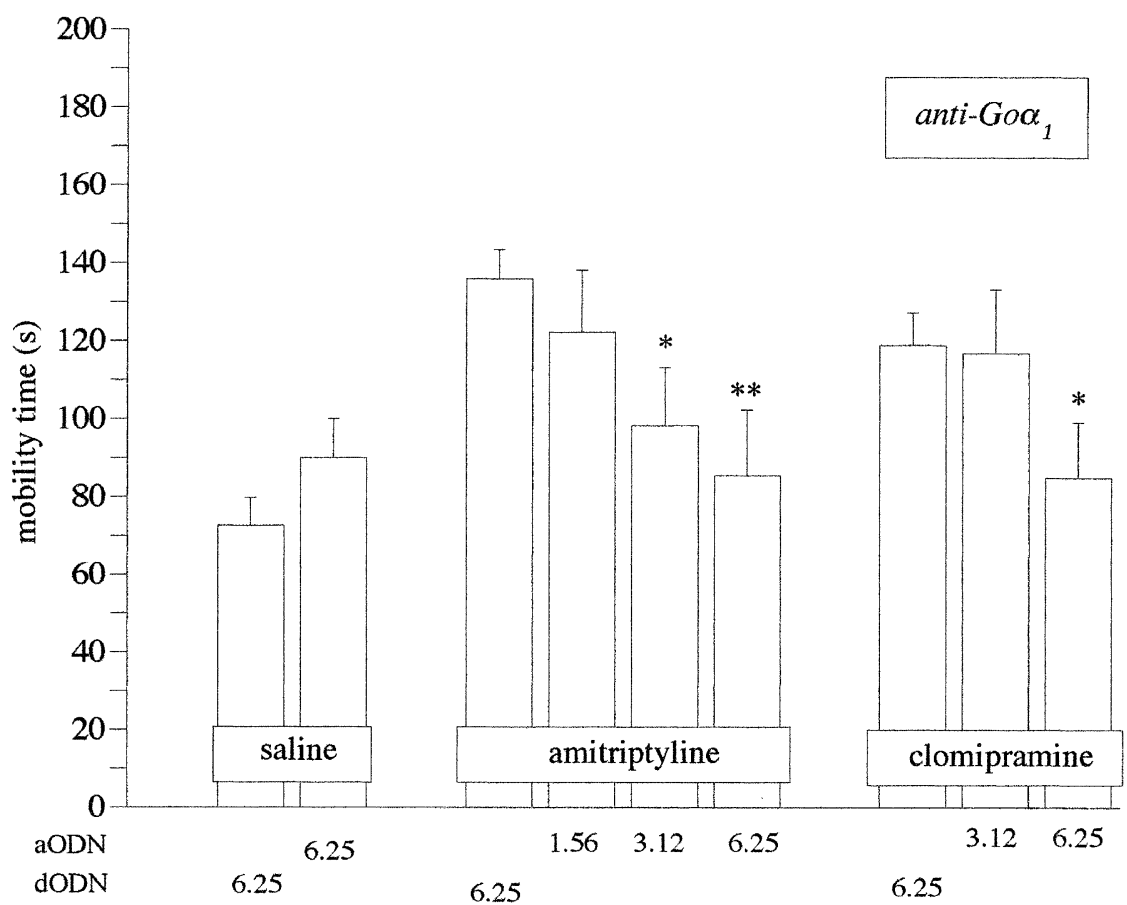

Figure 5. Prevention by pretreatment with an antisense oligonucleotide (aODN) to the $\alpha$ subunit of $\mathrm{Go}_{1}$-protein gene (1.56-6.25 $\mu \mathrm{g}$ per mouse i.c.v.) of amitriptyline (15 $\mathrm{mg} \mathrm{kg}^{-1}$ s.c.)- and clomipramine (25 mg kg-1 $\quad$ s.c.)-induced antidepressant-like effect in the mouse forced swimming test. The test was performed 18-24 h after the i.c.v. injection of degenerate ODN (dODN; $12.5 \mu \mathrm{g}$ per mouse i.c.v.) or aODN. Between 15 and 22 mice were tested. Vertical lines represent SEM; the dose administered is reported below each column. ${ }^{*} p<.05$, ${ }^{* *} p<.001$ in comparison with the corresponding TCA. 


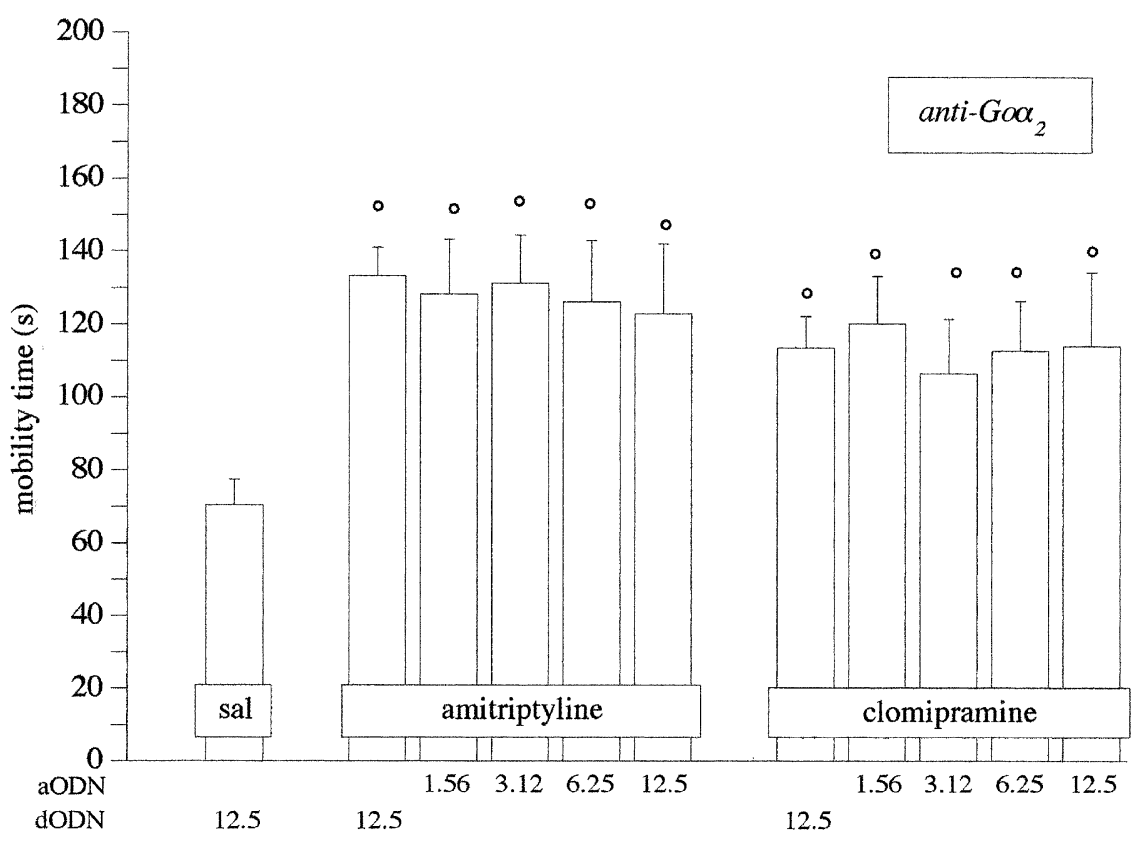

Figure 6. Lack of effect of pretreatment with an antisense oligonucleotide (aODN) to the $\alpha$ subunit of $\mathrm{Go}_{2}$-protein gene (1.56-12.5 $\mu$ g per mouse i.c.v.) on amitriptyline (15 $\mathrm{mg} \mathrm{kg}^{-1}$ s.c.)- and clomipramine (25 $\mathrm{mg} \mathrm{kg}^{-1}$ s.c.)-induced antidepressant-like effect in the mouse forced swimming test. The test was performed 18-24 $\mathrm{h}$ after the i.c.v. injection of degenerate ODN (dODN; $12.5 \mu \mathrm{g}$ per mouse i.c.v.) or aODN. Between 18 and 21 mice were tested. Vertical lines represent SEM; the dose administered is reported below each column. ${ }^{\circ} p<$ .01 in comparison with control group. this animal model has also some drawbacks represented by the possibility to obtain some false positives or negatives (Borsini and Meli 1988; Detke and Lucki 1996). Drugs enhancing motor activity, such as anticholinergics and antihistamines, may give a "false" positive effect in the forced swimming test and antidepressants such as bupropion, nomifensine, and amineptine would then be rejected since they increase motor activity (Borsini and Meli 1988).

Present results indicate that the activation of Gi proteins is required for the induction of the antidepressantlike effect produced by amitriptyline and clomipramine in the mouse forced swimming test. The administration of the investigated TCAs produced an increase of the mobility time that was prevented by pretreatment with pertussis toxin (PTX), a bacterial toxin produced by Bordetella pertussis that ADP-ribosylates and inactivates the $\alpha$ subunit of Gi-protein family (Katada and Ui 1982). These data confirm the important role played by $\mathrm{Gi}$ proteins in the signal transduction mechanism activated by amitriptyline and clomipramine. Gi-proteins represent the most widespread modulatory signaling pathway in neurones (Holtz et al. 1986) and one of their principal effect is the inhibition of adenylate cyclase activity (Sprang 1997). It has been reported that chronic treatment with several antidepressant drugs reduced the cAMP production stimulated by forskolin or noradrenaline (Mishra et al. 1980; Okada et al. 1986; Newman et al. 1993), further supporting the hypothesis of the involvement of this transduction system in the mechanism of action of amitriptyline and clomipramine.

The Gi protein subfamily is composed of several different members: $\mathrm{Gi}_{1}, \mathrm{Gi}_{2}, \mathrm{Gi}_{3}, \mathrm{Go}_{1}$, and $\mathrm{Go}_{2}$ (Simon et al. 1991). Since PTX inactivates all members of the Gi-pro- tein family, the role of each subtype was investigated by pretreating animals with aODNs against the $\alpha$ subunits of the above-mentioned Gi and Go protein subtypes. The inhibition of the expression of $\mathrm{Gi} \alpha_{1}, \mathrm{Gi} \alpha_{2}$, Gi $\alpha_{3}$ and Go $\alpha_{1}$ produced a dose-dependent prevention of TCA-induced increase of mobility time, whereas the administration of an aODN against $\mathrm{Go}_{2}$ never exerted any modification of amitriptyline and clomipramine activity. These results indicate a differential involvement of the Gi protein subtypes in the mechanism of action of the investigated tricyclic antidepressants. In particular, the integrity and functionality of $\mathrm{Gi}_{1}, \mathrm{Gi}_{2}, \mathrm{Gi}_{3}$, and $\mathrm{Go}_{1}$ proteins appears essential to produce the antidepressant-like effect observed. The $\mathrm{Gi}_{3}$ and $\mathrm{Go}_{1}$ subtypes appear to be endowed with a prominent role since the anti- $\mathrm{Gi}_{3}$ and anti-Go $\mathrm{G}_{1}$ prevent the increase of mobility time induce by both investigated TCAs at doses lower than anti- $\mathrm{Gi}_{1}$ and anti- $\mathrm{Gi}_{2}$. By contrast, the $\mathrm{Go}_{2}$ subtype, in these experimental conditions, appears not to be involved implying that this subunit is not a major component of transduction mechanisms leading to the amitriptyline and clomipramine antidepressant effect.

Chronic treatment with TCAs induces an increase in the Go-protein levels in different rat brain regions, such as frontal cortex, midbrain and hypothalamus (Lesch et al. 1991; Lesch and Manji 1992). Moreover, Yamamoto et al. (1992) reported that several TCAs, including clomipramine, were able to increase, in a PTX-dependent manner, the GTPase activity of Go proteins, purified from bovine brain membranes, indicating the ability of these compounds to directly stimulate Go proteins. Therefore, the important role played by $\mathrm{Go}_{1}$ proteins in amitriptyline and clomipramine antidepressant-like activity could be due, at least in part, to a di- 

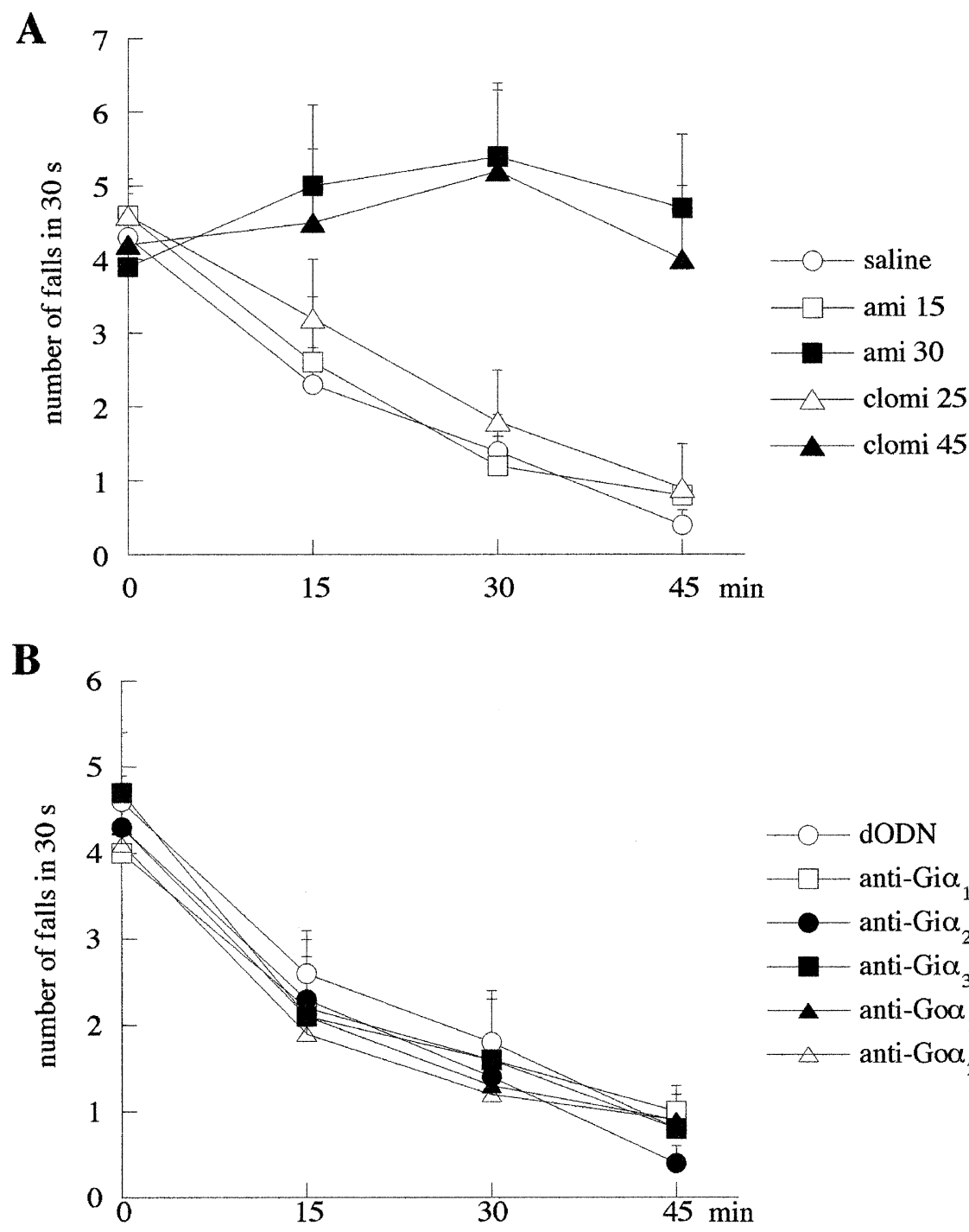

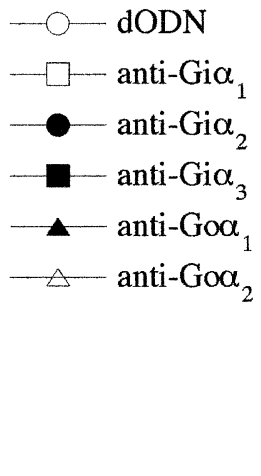

Figure 7. A. effect of amitriptyline and clomipramine on motor coordination in the mouse rota-rod test. Amitriptyline (15-30 $\mathrm{mg} \mathrm{kg}^{-1}$ s.c.) and clomipramine (25-45 $\mathrm{mg} \mathrm{kg}^{-1}$ s.c.) were administered $30 \mathrm{~min}$ before the test. B. effect of pretreatment with an aODN to the $\alpha$ subunit of $\mathrm{Gi}_{1^{-}}(12.5 \mu \mathrm{g}$ per mouse i.c.v.), $\mathrm{Gi}_{2^{-}}$(12.5 $\mu \mathrm{g}$ per mouse i.c.v.), $\mathrm{Gi}_{3^{-}}$(6.25 $\mu \mathrm{g}$ per mouse i.c.v.), $\mathrm{Go}_{1^{-}}$(6.25 $\mu \mathrm{g}$ per mouse i.c.v.), $\mathrm{Go}_{2^{-}}$ (12.5 $\mu$ g per mouse i.c.v.) protein gene on motor coordination in the mouse rota-rod test. The test was performed 18-24 $\mathrm{h}$ after the i.c.v. injection of dODN (12.5 $\mu \mathrm{g}$ per mouse i.c.v.) or aODN. Vertical lines represent SEM. rect activation of the Go-protein subtype. Nevertheless, it has been observed that chronic treatment with the antidepressant drug imipramine decreases Go $\alpha$ mRNA levels in the rat hippocampus without modifying Gi $\alpha$ mRNA levels (Lason and Przewlocki 1993). This discrepancy may stem from the heterogeneity of biological sample used (rat frontal cortex, midbrain and hypothalamus, bovine brain membranes, rat hippocampus) suggesting not only a differential effect of TCAs on different cerebral areas, but also a different involvement of the various brain regions in the induction of a depressive state condition. However, a change in the mRNA amount does not always imply defective protein function, but rather often appears to reflect compensatory consequences. As matter of fact, even if no clear alteration at mRNA Go protein level emerged, an increased functionality of this transduction mechanism after antidepressant treatment has been evidenced. Concerning $\mathrm{Gi}_{3}$, a reduction of this Gi-protein subtype has been observed in the platelets from patients suffering from ma- jor depression (Garcia-Sevilla et al. 1997). On these bases we can hypothesize that amitriptyline and clomipramine might exert their antidepressant effect by stimulating $\mathrm{Gi}_{3}$ subtypes in order to balance its deficiency.

A role in the mechanism of action of TCAs played by $\mathrm{Gi}_{2}$ proteins has been reported in humans. A reduced coupling capability of $\alpha_{2}$-adrenoceptors, a receptor subtype involved in the induction of depression (GarciaSevilla et al. 1999), with $\mathrm{Gi}_{2}$ proteins has been observed in platelets from patients suffering from major depression. In consequence, an increase of $\mathrm{Gi}_{2}$ proteins has been produced as a compensation mechanism (Karege et al. 1996). In these patients, repeated treatment with TCAs was reported to normalize the coupling of $\alpha_{2}$ adrenoceptors with $\mathrm{Gi}_{2}$ proteins, inducing, consequently, a reduction of $\mathrm{Gi}_{2}$ levels (Garcia-Sevilla et al. 1997; Karege et al. 1998). However, in our experimental conditions, the involvement of the $\mathrm{Gi}_{1}$ and $\mathrm{Gi}_{2}$ subtypes in the mechanism of action of amitriptyline and clomipramine has been observed after administration of a dose of aODN 
Table 2. Lack of Effect on Spontaneous Motility and Inspection Activity by Amitriptyline, Clomipramine, PTX, dODN and aODNs in the Mouse Hole-board Test.

\begin{tabular}{|c|c|c|c|}
\hline \multirow[b]{2}{*}{ Pre-Treatment (i.c.v.) } & \multirow[b]{2}{*}{ Treatment (s.c.) } & \multicolumn{2}{|c|}{ Counts in $5 \mathrm{~min}$} \\
\hline & & spontaneous motility & inspection activity \\
\hline Vehicle & Saline & $37.8 \pm 5.9$ & $63.4 \pm 6.7$ \\
\hline PTX $0.25 \mu \mathrm{g}$ & Saline & $35.1 \pm 4.8$ & $65.3 \pm 7.2$ \\
\hline Saline & Saline & $36.8 \pm 4.3$ & $63.1 \pm 5.1$ \\
\hline DOTAP $13 \mu \mathrm{M}$ & Saline & $37.8 \pm 3.1$ & $61.9 \pm 6.1$ \\
\hline dODN $12.5 \mu \mathrm{g}$ & Saline & $38.7 \pm 3.6$ & $61.7 \pm 5.6$ \\
\hline Anti-Gi $i_{1 \alpha} 12.5 \mu \mathrm{g}$ & Saline & $45.2 \pm 4.2$ & $65.7 \pm 3.3$ \\
\hline Anti-Gi ${ }_{2 \alpha} 12.5 \mu \mathrm{g}$ & Saline & $37.9 \pm 3.8$ & $61.4 \pm 4.4$ \\
\hline Anti-Gi $\mathrm{i}_{3 \alpha} 6.25 \mu \mathrm{g}$ & Saline & $41.9 \pm 4.7$ & $63.3 \pm 7.8$ \\
\hline Anti-Go $\mathrm{Go}_{1 \alpha} 6.25 \mu \mathrm{g}$ & Saline & $39.4 \pm 4.5$ & $62.9 \pm 6.5$ \\
\hline Anti-Go $\mathrm{G}_{2 \alpha} 12.5 \mu \mathrm{g}$ & Saline & $34.1 \pm 2.8$ & $59.7 \pm 6.0$ \\
\hline Saline & Amitriptyline 15 mg kg-1 & $36.0 \pm 4.5$ & $62.0 \pm 6.1$ \\
\hline Saline & Clomipramine $25 \mathrm{mg} \mathrm{kg}^{-1}$ & $36.0 \pm 4.5$ & $62.0 \pm 6.1$ \\
\hline Saline & Amphetamine $2 \mathrm{mg} \mathrm{kg}^{-1}$ & $73.2 \pm 7.1^{* *}$ & $104.8 \pm 12.0^{* *}$ \\
\hline
\end{tabular}

Pertussis toxin (PTX) and ODNs were injected respectively 11 days and $24-18 \mathrm{~h}$ before the test. ${ }^{* *} p<0.01$ in comparison with saline-saline treated mice.

two times higher than that necessary to produce a comparable effect with the anti-Gi $i_{3}$ and the anti-Go $\mathrm{G}_{2}$. These results, nevertheless, confirm the importance of the involvement of these two Gi-protein subtypes in the antidepressant-like effect induced by the two TCAs, and they also indicate a secondary role in comparison with $\mathrm{Gi}_{3}$ and $\mathrm{Go}_{2}$. Moreover, chronic and subchronic treatment with TCAs did not produce significant differences on $\mathrm{Gi}_{1}$ and $\mathrm{Gi}_{2}$ protein and mRNA levels in rat brain $(\mathrm{Li}$ et al. 1993; Lason and Przewlocki 1993; Emamghoreishi et al. 1996; Dwivedi and Pandey 1997), further supporting the hypothesis of a minor role for these two Gi-protein subtypes.

The two investigated TCAs induced their antidepressant-like effect by acting centrally since pertussis toxin and aODNs exerted their antagonistic effect after i.c.v. administration. However, substances injected i.c.v. can diffuse from the cerebral ventricles to the whole brain. It is, therefore, difficult to define potential site of actions of aODNs or pertussis toxin within the CNS.

Amitriptyline and clomipramine are inhibitors of the reuptake of serotonin and noradrenaline, two neurotransmitters involved in the modulation of mood. Some serotonin receptor subtypes as well as $\alpha_{2}$ adrenoceptors (Birnbaumer 1990) are Gi-protein coupled receptors within the central nervous system. We cannot, therefore, exclude the involvement of both neurotransmission systems in the induction of the antidepressantlike effects by the two investigated TCAs.

Pretreatment with aODN, at the highest effective doses, did not produce any modification of mobility time in the mouse forced swimming test. We can, therefore, conclude that the prevention of amitriptyline and clomipramine antidepressant-like effect is not due to a depressant-like effect exerted by these treatments. Fur- thermore, pretreatment with dODN, used as the reference ODN, never modified the increase of mobility time induced by the two investigated TCAs in comparison with saline-treated animals (data not shown), which excludes the possibility of a sequence-independent effect induced by the aODNs.

Numerous hormones and neurotransmitters activate the Gi-protein system. The administration of PTX and aODN against the $\alpha$ subunits of Gi proteins could induce side effects that make the interpretation of the results difficult. Furthermore, since drugs that modify motor activity may give false positive or negative effect, it is suitable to carry out a test to check this aspect, in parallel with forced swimming test. The highest doses of the drugs used in the present work were the maximum that did not produce behavioral side effects. The tricyclic antidepressants amitriptyline and clomipramine, as well as ODNs, at the highest doses used, did not modify animal's gross behavior. All the substances used were tested on the rota-rod test before the forced swimming test was performed, to make sure that they did not influence the normal motor coordination of the mice. Since ataxic mice are not able to coordinate movements and thus fall from the rotating rod, while excited animals tend to jump off the rod, the good performance on the rod by mice in the present study indicates the results obtained with the forced swimming test are not due to altered motor activity induced by substances at the doses used. Furthermore, not only altered motor coordination but also a modified spontaneous motility could lead to a misinterpretation of the results obtained in the forced swimming test. An influence of the substances used on spontaneous motility has, therefore, been excluded by using the hole-board test. Moreover, drugs which have a known psychostim- 
ulant effect, like (+)-amphetamine and caffeine, at the same doses at which they are able to increase the time of mobility in the rat forced swimming test, also show a significant increased motor activity in an open field (Porsolt et al. 1978).

In conclusion, our results evidence the important role played by $\mathrm{Gi} \alpha_{1}, \mathrm{Gi} \alpha_{2}$, Gi $\alpha_{3}$, and $\mathrm{Go} \alpha_{1}$, but not by $\mathrm{GoO}_{2}$, in the anti-immobility effect induced by amitriptyline and clomipramine.

\section{ACKNOWLEDGMENTS}

This work was supported by grants from MURST.

\section{REFERENCES}

Birnbaumer L (1990): G proteins in signal transduction. Annu Rev Pharmacol Toxicol 30:675-705

Borsini F, Meli A (1988): Is the forced swimming test a suitable model for revealing antidepressant activity? Psychopharmacology (Berl) 94:147-160

Bourin M, Colombel MC, Maligne M, Bradwejn J (1991): Clonidine as a sensitizing agent in the forced swimming test for revealing antidepressant activity. J Psychiatr Neurosci 16:199-203

Capaccioli S, Di Pasquale G, Mini E, Mazzei T, Quattrone A (1993): Cationic lipids improve antisense oligonucleotide uptake and prevent degradation in cultured cells and in human serum. Biochem Biophys Res Comm 107: 818-825

Chen J, Rasenick MM (1995): Chronic antidepressant treatment facilitates $G$ protein activation without altering $G$ protein content. J Pharmacol Exp Ther 275:509-517

Detke MJ, Lucki I (1996): Detection of serotoninergic and noradrenergic antidepressants in the rat forced swimming test: the effects of water depth. Behav Brain Res 73:43-46

Donati RJ, Thukral C, Rasenick MM (2001): Chronic treatment of C6 glioma cells with antidepressant drugs results in a redistribution of Gs $\alpha$. Mol Pharmacol 59: 1426-1432

Duman RS, Heninger GR, Nestler EJ (1997): A molecular and cellular theory of depression. Arch Gen Psychiatr 54:597-606

Dwivedi Y, Pandey GN (1997): Effects of subchronic administration of antidepressants and anxiolytics on levels of the alpha subunits of $G$ proteins in the rat brain. J Neural Transm 104:747-760

Emamghoreishi M, Warsh JJ, Sibony D, Li PP (1996): Lack of effect of chronic antidepressant treatment on Gs and Gi alpha-subunit protein and mRNA levels in the rat cerebral cortex. Neuropsychopharmacology 15:281-287

Garcia-Sevilla JA, Escriba PV, Ozaita A, La Harpe R, Walzer C, Eytan A, Guimon J (1999): Up-regulation of immunolabeled alpha2A-adrenoceptors, Gi coupling proteins, and regulatory receptor kinases in the prefrontal cortex of depressed suicides. J Neurochem 72:282-291

Garcia-Sevilla JA, Walzer C, Busquets X, Escriba PV, Balant L, Guimon J (1997): Density of guanine nucleotide-bind- ing proteins in platelets of patients with major depression: increased abundance of the $\mathrm{G} \alpha_{\mathrm{i} 2}$ subunit and down-regulation by antidepressant drug treatment. Biol Psychiatry 42:704-712

Haley TJ, McCormick WG (1957): Pharmacological effects produced by intracerebral injection of drugs in the conscious mouse. Br J Pharmacol Chemother 12:12-15

Henringer GR, Charney DS (1987): Mechanism of action of antidepressant treatments: Implications for the etiology and treatment of depressive disorders. In Meltzer HY (ed), Psychopharmacology: The Third Generation of Progress, New York, Raven Press, pp 535-544

Hille B (1994): Modulation of ion-channel function by G-protein-coupled receptors. Trends Neurosci 17:531-536

Holtz GG, Rane SG, Dunlap K (1986): GTP-binding proteins mediate transmitter inhibition of voltage-dependent calcium channels. Nature 319:670-672

Kamada H, Saito T, Hatta S, Toki S, Ozawa H, Watanabe M, Takahata N (1999): Alterations of tubulin function caused by chronic antidepressant treatment in rat brain. Cell Mol Neurobiol 19:109-117

Karege F, Bovier P, Rudolph W, Gaillard JM (1996): Platelet phosphoinositide signaling system: an overstimulated pathway in depression. Biol Psychiatry 39:697-702

Karege F, Bovier P, Stepanian R, Malafosse A (1998): The effect of clinical outcome on platelet $\mathrm{G}$ proteins of major depressed patients. Eur Neuropsychopharmacol 8:89-94

Katada T, Ui M (1982): Direct modification of the membrane adenylate cyclase system by islet-activating protein due to ADP ribosilation of a membrane protein. Proc Natl Acad Sci USA 79:3129-3133

Kleuss C, Hescheler J, Ewel C, Rosenthal W, Schultz G, Wittig B (1991): Assignment of G-protein subtypes to specific receptors inducing inhibition of calcium currents. Nature 353:43-48

Lason W, Przewlocki R (1993): The effect of chronic treatment with imipramine on the $G$ proteins mRNA level in the rat hippocampus - an interaction with a calcium channel antagonist. Pol J Pharmacol 45:219-226

Lesch KP, Manji HK (1992): Signal-transducing G proteins and antidepressant drugs: evidence for modulation of alpha subunit gene expression in rat brain. Biol Psychiatry 32:549-579

Lesch KP, Aulakh CS, Tolliver TJ, Hill JL, Murphy DL (1991): Regulation of G proteins by chronic antidepressant drug treatment in rat brain: tricyclics but not clorgyline increase Go alpha subunits. Eur J Pharmacol 207:361-364

Li PP, Young LT, Tam YK, Sibony D, Warsh JJ (1993): Effects of chronic lithium and carbamazepine treatment on G-protein subunit expression in rat cerebral cortex. Biol Psychiatry 34:162-170

Mazzola-Pomietto P, Azorin JM, Tramoni V, Jeanningros R (1994): Relation between lymphocyte beta-adrenergic responsivity and the severity of depressive disorders. Biol Psychiatry 35:920-925

Menkes DB, Rasenick MM, Wheeler MA, Bitensky MW (1983): Guanosine triphosphate activation of brain adenylate cyclase: enhancement by long-term antidepressant treatment. Science 219:65-67 
Mishra R, Janowsky A, Sulser F (1980): Action of mianserin and zimelidine on the norepinephrine receptor coupled adenylate cyclase system in brain: subsensitivity without reduction in $\beta$-adrenergic receptor binding. Neuropharmacology 19:983-987

Newman ME, Lerer B, Shapira B (1993): 5-HT 1A $_{\text {A }}$ receptormediated effects of antidepressants. Prog Neuropsychopharmacol Biol Psychiatry 17:1-19

Nibuya M, Nestler EJ, Duman RS (1996): Chronic antidepressant administration increases the expression of cAMP respons element binding protein (CREB) in rat hippocampus. J Neurosci 16:2365-2372

Okada F, Tokumitsu Y, Ui M (1986): Desensitization of $\beta$-adrenergic receptor-coupled adenylate cyclase in cerebral cortex after in vivo treatment of rats with desipramine. J Neurochem 47:454-459

Ozawa H, Rasenick MM (1989): Coupling of the stimulatory GTP-binding protein Gs to rat synaptic membranes adenylate cyclase is enhanced subsequent to chronic antidepressant treatment. Mol Pharmacol 36: 803-808

Porsolt RD, Anton G, Blavet N, Jalfre M (1978): Behavioural despair in rats: a new model sensitive to antidepressant treatments. Eur J Pharmacol 47:379-391

Porsolt RD, Bertin A, Jalfre M (1977): Behavioural despair in mice: A primary screening test for antidepressants. Arch Int Pharmacodyn 229:327-336

Raap DK, Evans S, Garcia F, Li Q, Muma NA, Wolf WA, Battaglia G, Van De Kar LD (1999): Daily injections of fluoxetine induce dose-dependent desensitization of hypothalamic $5-\mathrm{HT}_{1 \mathrm{~A}}$ receptors: reductions in neuroendocrine responses to 8-OH-DPAT and in levels of $\mathrm{Gz}$ and Gi proteins. J Pharmacol Exp Ther 288:98-106

Raffa RB, Martinez RP, Connelly CD (1994): G-protein anti- sense oligodeoxynucleotides and $\mu$-opioid supraspinal antinociception. Eur J Pharmacol 258:R5-7

Sanchez-Blazquez P, Garzon J (1998): Delta opioid subtypes activates inositol-signaling pathways in the production of antinociception. J Pharmacol Exp Ther 285:820-827

Sanchez-Blazquez P, Garcia-Espana A, Garzon J (1995): In vivo injection of oligodeoxynucleotides to $G \alpha$ subunits and supraspinal evoked by $\mathrm{mu}$ and delta opioid agonists. J Pharmacol Exp Ther 275:1590-1596

Schildkraut JJ (1965): The catecholamine hypothesis of affective disorders: a review of supporting evidence. Am J Psychiatry 122:509-522

Simon MI, Strathman MP, Gautman N (1991): Diversity of G proteins in signal transduction. Science 252:802-808

Sprang SR (1997): G-protein mechanisms: insights from structural analysis. Annu Rev Biochem 66:639-668

Thome J, Sakai N, Shin K, Steffen C, Zhang Y, Impey S, Storm D, Duman RS (2000): cAMP response elementmediated gene transcription is up-regulated by chronic antidepressant treatment. J Neurosci 20:4030-4036

Vaught J, Pelley K, Costa LG, Sether P, Enna SJ (1985): A comparison of the antinociceptive responses to GABAreceptor agonists THIP and baclofen. Neuropharmacology 24:211-216

Willner P (1984): The validity of animal models for depression. Psychopharmacology (Berl) 83:1-16

Yamamoto H, Tomita U, Mikuni M, Kobayashi I, Kagaya A, Katada T, Ui M, Takahashi K (1992): Direct activation of purified Go-type GTP binding protein by tricyclic antidepressants. Neurosci Lett 139:194-196

Yamaoka K, Nanba T, Nomura S (1988): Direct influence of antidepressants on GTP binding protein of adenylate cyclase in cell membranes of the cerebral cortex of rats. J Neural Transm 71:165-175 